\title{
EPIDEMIOLOGY OF COVID-19: WHAT HAVE WE LEARNT UNTIL NOW?
}

\author{
EPIDEMIOLOGIJA KOVID-19: ŠTA SMO NAUČILI DO SADA?
}

Tatjana Pekmezović ${ }^{1}$

${ }^{1}$ Univerzitet u Beogradu, Medicinski fakultet, Institut za epidemiologiju, Beograd, Srbija

Correspondence: pekmezovic@sezampro.rs

\section{Abstract}

The first case in the outbreak of atypical pneumonia of unknown etiology, later confirmed as disease caused by SARS-CoV-2, was described in Wuhan (China) on December 8, 2019. The rapid expansion of COVID-19 cases prompted the World Health Organization (WHO) to declare a global health emergency, and on March 11, 2020, COVID-19 was officially classified as a pandemic disease by the WHO. It is generally accepted that both genders and all ages in the population are susceptible to SARS-CoV-2 infection. Data from the real life also show difficulties in reaching the threshold of herd immunity. Thanks to the vaccination, some populations are approaching the theoretical threshold of immunity, but the spread of the virus is still difficult to stop. If we add to that the fact that we still do not know how long immunity lasts after the infection, the conclusion is that vaccination is unlikely to completely stop the spread of the virus, and that we must think about it. Vaccines certainly significantly reduce the hospitalization rate and mortality rate, and the assumption is that the virus will not disappear soon, but the severity of the disease and its fatality will be of marginal importance. The development of the

Keywords:

COVID-19,

epidemiology, herd immunity, prevention epidemiological situation related to the COVID-19 is constantly changing and it significantly differs in various parts of the world, which is affected by differences in financial resources, health infrastructure and awareness of prevention and control of the COVID-19. Attempts are being made to make dynamically adjusted strategies in response to the COVID-19 pandemic, that is, the new normality.
Pekmezović T. MedPodml 2021, 72(3):8-11

(C)

The authors declare no conflicts of interest. doi:10.5937/mp72-34099

Editorial board: podmladak.med.bg@gmail.com 


\section{Sažetak}

Prvi slučaj u epidemiji atipične upale pluća nepoznate etiologije, kasnije potvrđen kao bolest uzrokovana virusom SARS-CoV-2, opisan je u Vuhanu (Kina), 8. decembra 2019. godine. Brzo širenje nove bolesti kovid-19 i posledice koje ostavlja podstakli su Svetsku zdravstvenu organizaciju (SZO) da proglasi globalnu zdravstvenu pretnju, a 11. marta 2020. godine, SZO je zvanično klasifikovala kovid-19 kao pandemijsku bolest. Opšte je prihvaćeno da su oba pola i svi uzrasti u populaciji podložni infekciji SARS-CoV-2. Podaci iz stvarnog života pokazuju poteškoće u dostizanju praga kolektivnog imuniteta. Zahvaljujući vakcinaciji, neke populacije se približavaju teorijskom pragu kolektivnog imuniteta, ali je širenje virusa i dalje teško zaustaviti. Ako tome dodamo i činjenicu da još uvek ne znamo koliko traje postinfektivni imunitet, zaključuje se da je malo verovatno da će vakcinacija potpuno zaustaviti širenje virusa i da se to mora imati u vidu. Vakcine svakako značajno smanjuju stopu hospitalizacije i mortalitet, a pretpostavka je da virus neće uskoro nestati,

Ključne reči:

COVID-19,

epidemiologija,

kolektivni imunitet, prevencija ali će težina bolesti i njen smrtni ishod biti od marginalnog značaja. Razvoj epidemiološke situacije povezane sa kovid-19 stalno se menja i značajno se razlikuje u različitim delovima sveta, na šta utiču razlike u finansijskim resursima, zdravstvenoj infrastrukturi i svesti o prevenciji i kontroli bolesti. Postoje pokušaji da se naprave dinamički prilagođene strategije kao odgovor na pandemiju kovid-19, koje bi predstavljale novu normalnost.
During the $20^{\text {th }}$ and at the beginning of the $21^{\text {st }}$ century, several pandemics of respiratory infections have occurred, out of which the most significant, from the aspect of mortality, was the Spanish fever pandemic in which 50 million people died. One hundred years later, the world was affected by a COVID-19 pandemic with almost 5 million deaths, and this number is still not final. In between, there were several influenza pandemics, but with a smaller number of deaths $(1,2)$. Regardless of the progress of medicine in all its areas, the ability to prevent, detect and treat COVID-19 was not sufficient to avoid the excess of mortality from infectious diseases in the $21 \mathrm{st}$ century (3). The age distribution of the dead people also distinguishes Spanish fever from COVID-19. Namely, the Spanish fever most often killed people between the ages of 25 and 30 , and $95 \%$ of deaths occurred in people under the age of 65 , while death from COVID-19, at least in the first epidemic waves, mainly affected the elderly $(4,5)$.

Epidemiological characteristics of COVID-19 infection

The first case in the outbreak of atypical pneumonia of unknown etiology, later confirmed as disease caused by SARS-CoV-2, was described in Wuhan (China) on December 8, 2019 (6). The rapid expansion of COVID-19 cases prompted the World Health Organization (WHO) to declare a global health emergency, and on March 11, 2020, COVID-19 was officially classified by the WHO as a pandemic disease (7). Up to now, globally, at the end of September 2021, there have been more than 228 million confirmed cases of COVID-19, including almost 5 million deaths, reported to the WHO (8). The highest number of affected persons was registered in the USA, India, Brazil and the UK, and countries with the highest deaths were the USA, Brazil, India and Mexico (8). In Serbia, according to the official data, number of COVID-19 cases exceeds 872.000, and number of deaths is almost 8.000 (9).
It is generally accepted that both genders and all ages in the population are susceptible to SARS-CoV-2 infection, and therefore, the COVID-19 can occur in people of any age, but the risk of an unfavorable course and outcome of the disease increases with age (10). Additionally, there is a clear evidence for human-to-human transmission of the new virus, which may be facilitated by certain activities such as travel, gatherings, and close contacts, often via small droplets that are produced by coughing, sneezing, and talking.

One of the most important epidemiological models of the disease is ecological triangle, which includes equilibrium among agent, host and environment. It is obvious that the virulence of the agent, SARS-CoV-2, has increased since the beginning of the pandemic (11). The key unfavorable host factors comprise older age and presence of comorbidities (10). Although the effects of climate variables on COVID-19 varied among different places and time, there were similar results showing that higher temperatures may have largely influenced the spread of coronavirus and suppressed the pandemic (12).

\section{Herd immunity}

The most important epidemiological concept in the outbreak regulation in general is herd immunity (13). It is defined as the resistance of a group of people to a disease in which a large part of the group members are immune. If a large percentage of the population is immune, the entire population is likely to be protected, not just those who are immune. This happens because the disease is transmitted from one person to another in any community. The presence of a large proportion of immune individuals in the population reduces the likelihood that a person with the disease will come into contact with a susceptible person. Why is the concept of herd immunity so important? When conducting immunization programs, it is not necessary to vaccinate every individual in order to achieve successful 
protection of the population. The certain conditions should be met, in order to achieve herd immunity. The causative agent must be limited to one type of host and transmission must be direct, from one member of the community to another. In addition, the disease must induce solid immunity. If the immunity is only partial, it would not be possible to achieve immunity in a large percentage of people in the community.

At the beginning of the COVID-19 epidemic, every individual in the population was susceptible. If an infected individual enters such a population, the infection spreads rapidly, but when a certain threshold is reached, new infected persons can no longer infect new susceptible persons, because by then the population developed acquired immunity, and the remaining non-immune individuals are indirectly protected. Thus, herd immunity prevents an infected person from introducing the agent into the population or minimizes agent transmission in the population (14).

How many resilient individuals need to be in the population to stop the pandemic spread of SARS-CoV-2?

This threshold of herd immunity depends on the basic reproduction number (R0), which indicates the average number of secondary infections caused by an infected person introduced into a fully susceptible population (15). Results of different recent investigations showed that R0 depends not only on the biological characteristics of the agent (SARS-CoV-2), but also on the social and cultural milieu of the population, which means that it can be different in different populations. Thus, it has recently been shown that R0 in Western European populations is 2.2, which is lower than in China where the average is over 3 , and there are also populations where it is around 6. Mathematically calculated, this means that the threshold of herd immunity is in the interval from $50 \%$ to $70 \%$, and definitely varies from population to population (16). However, due to the fact that the R0 of new variants of SARS-CoV-2 is $50-56 \%$ higher than that of wild type strains, this increased infectious potential of transmission raised the need to further increase the herd immunity threshold by about $10-12 \%$, without mitigating interventions, in order to achieve a new threshold of approximately $80 \%$ (17).

Data from the real life also show difficulties in reaching the threshold of herd immunity. Thanks to the vaccination, some populations are approaching the theoretical threshold of immunity, but the spread of the virus is still difficult to stop (18). If we add to that the fact that we still do not know how long immunity lasts after the infection, the conclusion is that vaccination is unlikely to completely stop the spread of the virus, and that we must think about it. Vaccines certainly significantly reduce the hospitalization rate and mortality rate, and the assumption is that the virus will not disappear soon, but the severity of the disease and its fatality will be of marginal importance (18). We should also keep in mind the results obtained based on the mathematical models that combined the immuno-epidemiological model with natural and post-vaccination immunity, the philodynamic evolutionary model and the virus adaptation model (19). These results show that in a population where vaccination coverage is low, virus adaptation and new variants occur more rapidly, with potentially more severe side effects.

\section{What could be expected from COVID-19 pandemic in the near future?}

The development of the epidemiological situation related to the COVID-19 is constantly changing and it significantly differs in various parts of the world, which is affected by differences in financial resources, health infrastructure and awareness of prevention and control of the COVID-19. Attempts are being made to make dynamically adjusted strategies in response to the COVID-19 pandemic "as a new normal" (20).

A group of experts (21) examined how the COVID 19 pandemic will develop in Europe. According to them key aspects that could affect the COVID-19 pandemic largely depend on the progress of national and global immunization programs, the emergence and spread of new variants of SARS-CoV-2, and the populations response to non-pharmacological interventions. The facts are that a large part of the world's population is still unvaccinated, that new variants of the virus are appearing that are spreading rapidly, which is affected by increased mobility and population mixing. For these reasons, too rapid or premature lifting of restrictions can be considered a risk for a new outbreak peak. In the fall of 2021, increased indoor activities could accelerate the spread of the virus again, and if the reintroduction of non-pharmacological measures is too slow, the occurrence of COVID-19 infection may rise sharply again and consequently increase the hospitalization and mortality rates. Therefore, it is necessary to maintain a moderate, adaptive level of non-pharmacological measures at all times. These epidemiological aspects, combined with the economic, social and health characteristics of the population, provide a holistic approach to the future of COVID-19 pandemic (21).

\section{Literature}

1. Conti AA. Historical evolution of the concept of health in Western medicine. Acta Biomed. 2018; 89(3):352-4.

2. Fineberg HV. Pandemic preparedness and response-lessons from the H1N1 influenza of 2009. N Engl J Med. 2014; 370(14):1335-42.

3. Hu B, Guo H, Zhou P, Shi ZL. Characteristics of SARS-CoV-2 and COVID-19. Nat Rev Microbiol. 2021; 19(3):141-54.

4. Woolf SH, Chapman DA, Sabo RT, Zimmerman EB. Excess Deaths From COVID-19 and Other Causes in the US, March 1, 2020, to January 2, 2021. JAMA. 2021; 325(17):1786-9.

5. Garber AM. Learning From Excess Pandemic Deaths. JAMA. 2021; 325(17):1729-30.

6. Wu F, Zhao S, Yu B, Chen YM, Wang W, Song ZG, et al. A new coronavirus associated with human respiratory disease in China. Nature. 2020; 579:265-9.

7. World Health Organization. Novel Coronavirus (2019-nCoV): Situation Report, 22. World Health Organization, 2020.

8. World Health Organization. COVID-19. 2021. Available from: https://covid19.who.int/. 
9. Institut za javno zdravlje Srbije „Dr Milan Jovanović Batut“. COVID-19. 2021. Available from: https://covid19.rs.

10. Hu B, Guo H, Zhou P, Shi ZL. Characteristics of SARS- CoV-2 and COVID-19. Nat Rev Microbiol. 2021; 19(3):141-54.

11. Alison S, Sofonea MT. SARS-CoV-2 virulence evolution: Avirulence theory, immunity and trade-offs. J Evol Biol. 2021; 00:1-11.

12. Zheng HL, Guo ZL, Wang ML, Yang C, An SY, Wu W. Effects of climate variables on the transmission of COVID-19: a systematic review of 62 ecological studies. Environ Sci Pollut Res Int. 2021; 00:1-18.

13. Celentano DD, Szklo M. Gordis Epidemiology. 6th edition. Philadelphia: Elsevier, 2019.

14. Dong M, He F, Deng Y. How to Understand Herd Immunity in the Context of COVID-19. Viral Immunol. 2021; 34(3):174-81.

15. Prajapati S, Kumar NGV. Assumption of Herd Immunity against COVID-19: A Plausibility and Hope or a Terrible Thought in Modern-Day to Save the Life. J Infect Dis Epidemiol. 2020; 6:147.

16. Locatelli I, Traachsel B, Rousson V. Estimating the basic reproduction number for COVID-19 in Western Europe. PLoS One. 2021; 16(3):e0248731.
17. Lippi G, Henry BM. How will emerging SARS-CoV-2 variants impact herd immunity? Ann Transl Med. 2021; 9(7):585.

18. Aschwanden C. Five reasons why COVID herd immunity is probably impossible. Nature. 2021; 591(7851):520-2.

19. Saad-Roy CM, Morris SE, Metcalf CJE, Mina MJ, Baker RE, Farrar J, et al. Epidemiological and evolutionary considerations of SARS-CoV-2 vaccine dosing regimes. Science. 2021; 372(6540):363-70.

20. Shen W. Dynamically adjusted strategy in response to developments in the COVID-19 pandemic as a new normal. Global Health. 2021; 17(1):89.

21. Iftekhar EN, Priesemann V, Balling R, Bauer S, Beutels P, Calero Valdez A, et al. A look into the future of the COVID-19 pandemic in Europe: an expert consultation. Lancet Reg Health Eur. 2021; 8:100185. 